Article

\title{
Photocatalytic Degradation of Humic Acids Using $\mathrm{LaFeO}_{3}$
}

\author{
Nazli Turkten ${ }^{1,+}\left(\mathbb{D}\right.$, Isabella Natali Sora ${ }^{2, *}$, Ayse Tomruk ${ }^{1}$ and Miray Bekbolet ${ }^{1}$ \\ 1 Institute of Environmental Sciences, Bogazici University, Bebek, Istanbul 34342, Turkey; \\ nazli.turkten@boun.edu.tr (N.T.); atomruk@boun.edu.tr (A.T.); bekbolet@boun.edu.tr (M.B.) \\ 2 Department of Engineering and Applied Sciences, University of Bergamo, viale Marconi 5, \\ 24044 Dalmine, Italy \\ * Correspondence: isabella.natali-sora@unibg.it; Tel.: +39-035-205-2012 \\ + Current address: Department of Chemistry, Faculty of Science and Arts, Ahi Evran University, \\ Kirsehir 40100, Turkey.
}

Received: 6 November 2018; Accepted: 4 December 2018; Published: 6 December 2018

check for updates

\begin{abstract}
TiO}_{2}$ photocatalytic degradation of dissolved organic matter (DOM), namely humic substances composed of humic (HA) and fulvic acids, has been investigated for decades. However, the application of non- $\mathrm{TiO}_{2}$ photocatalysis for this purpose has only received recent attention. Aiming to fill this gap, this study was performed to elucidate the photocatalytic degradation of HAs using the novel photocatalyst $\mathrm{LaFeO}_{3}$ (LF) under simulated solar light irradiation. HA was selectively fractionated by ultrafiltration to two different molecular size fractions representing high molecular fraction as $100 \mathrm{kDa}$ and lower molecular size fraction comprised of humic components expressing size fractions smaller than $30 \mathrm{kDa}$. Photocatalyst LF was prepared by the citrate auto-combustion method and characterized by using various techniques and Brunauer-Emmett-Teller (BET) surface area. Ultraviolet-visible (UV-vis) and excitation-emission matrix (EEM) fluorescence spectroscopic features were used to characterize the treated HA and photocatalytic mineralization extend was followed by dissolved organic carbon (DOC) contents. Photocatalytic performance of LF was compared to the metal modified version as $\mathrm{Cu}$-doped LF. Highest mineralization was achieved upon the use of a photocatalyst dose of $0.25 \mathrm{mg} / \mathrm{mL}$ of $\mathrm{LaFe}_{0.90} \mathrm{Cu}_{0.10} \mathrm{O}_{3-\delta}(\mathrm{Cu}-\mathrm{LF})$ for $30 \mathrm{kDaHA}$, whereas lowest mineralization was attained for $100 \mathrm{kDaHA}$ upon the use of LF. Photocatalytic degradation kinetics indicated the possible use of LF and $\mathrm{Cu}-\mathrm{LF}$ for the degradation of HA.
\end{abstract}

Keywords: humic acid; $\mathrm{LaFeO}_{3} ; \mathrm{Cu}-\mathrm{LaFeO}_{3}$; perovskite; solar photocatalysis; EEM

\section{Introduction}

Humic substances (HS) comprise the major fraction of natural dissolved organic matter (DOM) and are defined as a category of naturally occurring, biogenic, heterogeneous organic substances that can be generally characterized as being yellow-to-black in color, and of high molecular weight refractory organics [1]. Major fraction of HS is referred to as humic acids (HAs) that are "dark-colored organic molecules that can be extracted from soil by dilute alkali and other reagents and is insoluble in dilute acid" [2]. According to a general understanding, HAs are collections of diverse molecular mass (1-300 kDa) organic molecules forming dynamic supramolecular associations stabilized by hydrophobic interactions and hydrogen bonds. Therefore, their interactions with natural water constituents should be addressed as non-specific molecular size dependent reactivities leading to various manifold reactions.

Due to the adverse environmental significance of DOM in natural waters, removal of DOM by advanced oxidation techniques has been extensively studied under solar light irradiation [3-7]. 
In this field, $\mathrm{TiO}_{2}$ photocatalysis has been widely used for the removal of DOM, and more specifically, humic and fulvic acids [8,9]. Although $\mathrm{TiO}_{2}$ nanomaterials express superior parameters as being photo-stable, cheap, and non-toxic, they also pose major disadvantages due to the wide band-gap (anatase $\mathrm{E}_{\mathrm{bg}}=3.2 \mathrm{eV}$ and rutile $\mathrm{E}_{\mathrm{bg}}=3.0 \mathrm{eV}$ ) and fast recombination rate of photo-generated electrons and holes. In order to overcome UV light limitations, various methods were developed to modify $\mathrm{TiO}_{2}$ to extend light absorption efficiency to visible region [10]. Recent interest was also diverted to the understanding of non- $\mathrm{TiO}_{2}$ photocatalysts more specifically perovskites in comparison to $\mathrm{TiO}_{2}$ [11].

A review of the photocatalytic performance of visible light active perovskites was presented emphasizing on advantages and limitations [12]. $\mathrm{LaFeO}_{3}(\mathrm{LF})$ has been developed for the degradation of pollutants as well as hydrogen evolution under visible light. $\mathrm{LF}$ with a typical $\mathrm{ABO}_{3}$-type perovskite structure ( $\mathrm{A}$ is usually a rare earth and $\mathrm{B}$ is a transition metal) has proven to be effective on catalytic reactions owing to its significant properties as high stability and nontoxicity $[13,14]$. Furthermore, La ferrites, either sole or modified with various doping elements i.e., $\mathrm{Cu}, \mathrm{Sr}$, has been extensively investigated by Natali Sora et al. [15-25]. Focusing on specific application of La ferrites, reduction in eco-toxic effects of micropollutants was achieved via photocatalytic degradation [26].

Characterization of $\mathrm{LF}$ and $\mathrm{LaFe}_{0.90} \mathrm{Cu}_{0.10} \mathrm{O}_{3-\delta}(\mathrm{Cu}-\mathrm{LF})$ samples was reported previously and summarized as follows [21]. X-rays diffraction (XRD) patterns of the LF and Cu-LF samples revealed an orthorhombic single phase. XRD crystallite sizes of the perovskite phases calculated using Scherrer equation were 43 and $35 \mathrm{~nm}$ for LF and Cu-LF samples, respectively. Specific surface areas were determined as 13 and $16 \mathrm{~m}^{2} / \mathrm{g}$ for LF and Cu-LF, respectively. Scanning electron microscope (SEM) images of LF and $\mathrm{Cu}-\mathrm{LF}$ displayed almost spherical agglomerates of particles. Optical band-gap $\mathrm{E}_{\mathrm{bg}}$ of $\mathrm{LF}$ and $\mathrm{Cu}$-LF samples were estimated assuming a direct allowed transition by extrapolating a linear fitting in the Tauc plot. LF sample exhibited $\mathrm{E}_{\mathrm{bg}}=2.56-2.64 \mathrm{eV}$, and Cu-LF sample $\mathrm{E}_{\mathrm{bg}}=2.51-2.58 \mathrm{eV}$. These values indicated the possibility of using simulated solar light for the degradation of natural organic matter. In an XPS analysis of the samples, the presence of peak centered at circa $710.5 \mathrm{eV}$ corresponded to $\mathrm{Fe} 2 \mathrm{p}_{3 / 2}$ showing $\mathrm{Fe}(\mathrm{III})$ ions in the oxidizing environment. The binding energy for $\mathrm{O} 1 \mathrm{~s}$ was obtained at $529.2 \mathrm{eV}$ and a weak second peak at circa $531 \mathrm{eV}$ that might be assigned to a hydroxylation and/or carbonation at the perovskites surface. In the C1s spectrum, a weak second peak at circa $289.4 \mathrm{eV}$ was detected that might be associated with the formation of surface carbonates.

LF has been shown to express narrow band-gap energy leading to successful utilization as a semiconductor material for photocatalysis [27-29]. Shape-dependent photocatalytic activity of LF had been elucidated under visible light irradiation using rhodamine black dye as the model compound [30]. Material preparation and activity testing using common dyes, i.e., rhodamine B [31]; methyl orange [32]; and methylene blue [33] were presented. In general, LF photocatalyst has been applied for the degradation of various organics expressing diverse chemical compositions; however, neither of the organics could be regarded as representatives of building blocks or sub-compounds of humic matter [34].

Upon the use of LF specimens under light irradiation, the prevailing reaction mechanism indicating the primary reactions leading to the formation reactive oxygen species (ROS) has not been investigated in detail. Based on the experimental results, ${ }^{\bullet} \mathrm{OH}$ and ${ }^{\bullet} \mathrm{O}_{2}{ }^{-}$were reported as the main active species causing degradation of a model dye compound [35]. Primary e- $/ \mathrm{h}+$ pair formation mechanism was expressed upon the use of $\mathrm{LaFeO}_{3} / \mathrm{TiO}_{2}$ composite under visible light irradiation [32].

The use of $\mathrm{LF}$ as a non- $\mathrm{TiO}_{2}$ photocatalyst had not been reported so far for the removal of DOM and its analog compounds to the best of our knowledge. Therefore, HA was chosen as a representative compound of DOM that was further processed to lower molecular size fractions to represent diverse sub-groups displaying different chemical compositions. Solar photocatalytic degradation of HA was investigated by using LF and Cu-LF. With the aim of determining the photocatalytic degradation kinetics, degradation rates of HA fractions were elucidated by UV-vis spectral analysis and DOC 
parameters. Organic matter characterization was further extended to EEM (excitation-emission matrix) fluorescence features.

\section{Results and Discussion}

\subsection{Photocatalytic Degradation of $H A$}

DOC contents of the HA samples were $7.89 \mathrm{mg} / \mathrm{L}$ and $2.60 \mathrm{mg} / \mathrm{L}$ for $100 \mathrm{kDaHA}$ and $30 \mathrm{kDaHA}$ fractions, respectively. As expected, the UV-vis spectroscopic parameters (absorbance values) for both molecular size fractions followed the general trend $U_{254}>U_{280}>U_{365}>C_{10} V_{436}$ [36]. As an indicator parameter of aromaticity, $\mathrm{CbUV}_{254}$ (carbon based $\mathrm{UV}_{254}, \mathrm{~L} / \mathrm{mg} \mathrm{m}$ ) values were 9.47 and 6.89 for $100 \mathrm{kDaHA}$ and $30 \mathrm{kDaHA}$, respectively. $100 \mathrm{kDaHA}$ expressed more aromatic character, as expected. Expressing the ratio of aromaticity to color forming moieties, $\mathrm{UV}_{280} / \mathrm{Color}_{436}$ values were 5.14 and 5.35 for $100 \mathrm{kDA}$ and $30 \mathrm{kDaHA}$, respectively [37,38].

Photocatalytic degradation profiles of $100 \mathrm{kDaHA}$ and $30 \mathrm{kDaHA}$ were assessed upon irradiation periods of $0-60 \mathrm{~min}$ using $0.25 \mathrm{mg} / \mathrm{mL}$ and $0.50 \mathrm{mg} / \mathrm{mL}$ catalyst doses. Under all conditions, UV-vis spectra retained a humic-like profile displaying a decreasing logarithmic trend with respect to increasing wavelength (Figure 1). Upon the use of LF, UV-vis spectroscopic profiles expressed distinctly different removal kinetics for both of the HA molecular size fractions irrespective of the applied dose. As could be visualized from the spectra, color forming moieties $(\lambda>400 \mathrm{~nm})$ were significantly removed in comparison to UV absorbing centers upon an irradiation period of $60 \mathrm{~min}$. An extended irradiation period up to $120 \mathrm{~min}$ resulted in extensive removal of all UV-vis parameters although complete mineralization could not be attained $(<20 \%)$. A different behavior was found with $\mathrm{Cu}-\mathrm{LF}$; the effect of photocatalyst dose was more significant in comparison to humic organic matter content and molecular size fraction. Surface interaction should be expected to play a major role prior to the initiation of the photocatalysis. UV absorbing centers $(\lambda<400 \mathrm{~nm})$ were still evident under all conditions upon the use of $\mathrm{Cu}-\mathrm{LF}$, whereas color forming moieties $(\lambda>450 \mathrm{~nm})$ were still evident upon the use of $100 \mathrm{kDaHA}$ in the presence of both doses as $0.25 \mathrm{mg} / \mathrm{mL}$ and $0.50 \mathrm{mg} / \mathrm{mL}$ in comparison to the lower molecular size fraction of HA at $30 \mathrm{kDaHA}$.

Instantaneous adsorption occurring upon the introduction of the photocatalyst specimens to the humic solution ( $\mathrm{t}=0$ condition) indicated prevailing surface interactions prior to the initiation of photocatalytic treatment fulfilling the prerequisite of surface adsorption. Based on the $\mathrm{UV}_{254}$ parameter, a comparative evaluation could be assessed as follows: (i) upon the use of $0.25 \mathrm{mg} / \mathrm{mL} \mathrm{LF}(13.60 \%$ $100 \mathrm{kDaHA}$ and $18.42 \% 30 \mathrm{kDaHA}$ ), surface coverage extent due to the increase in humic molecular size could not be regarded as significant, (ii) upon an increase in dose to $0.50 \mathrm{mg} / \mathrm{mL}(38.52 \% 100 \mathrm{kDaHA}$ and $29.02 \% 30 \mathrm{kDaHA}$ ), $100 \mathrm{kDaHA}$ was more prone to surface attractions, (iii) Cu-LF dosage did not considerably affect the initial adsorption being more significant for $30 \mathrm{kDaHA}(46.83 \%$ for $0.25 \mathrm{mg} / \mathrm{mL}$ and $51.28 \%$ for $0.50 \mathrm{mg} / \mathrm{mL})$ in comparison to $100 \mathrm{kDaHA}(10.79 \%$ for $0.25 \mathrm{mg} / \mathrm{mL}$ and $16.08 \%$ for $0.50 \mathrm{mg} / \mathrm{mL}$ ). Lower molecular size HA fractions could contain more functional groups composed of carboxylic $\left(\mathrm{pK}_{\mathrm{a}} 3-5\right)$ and phenolic groups $\left(\mathrm{pK}_{\mathrm{a}}>8\right)$ that could be considered as partially deprotonated open to exposure to photocatalyst surface via electrostatic attractions. It has been reported that the point of zero charge (PZC) of LF was 8.9 [39]. At solution $\mathrm{pH}$ values lower than the PZC value (as in this case $\mathrm{pH}$ 6-7), the adsorbent surface was positively charged attracting negatively charged species. The negatively charged deprotonated humic groups, formed in the aforementioned $\mathrm{pH}$ range, could be the dominant groups that interacted with the catalyst surface. It should also be mentioned that under all conditions, adsorption extent was $<50 \%$ excluding extensive surface coverage that could diminish light absorption leading to retardation of degradation efficiency.

$\mathrm{UV}_{280} /$ Color $_{436}$ variations expressed inconsistent trends with respect to both photocatalyst type and dose revealing diverse role of absorption centers. Although the extent of initial surface coverage by humic sub-fractions could be regarded as sufficient for initiation of photocatalysis, a plausible reaction mechanism could not be attributed to any specific role of aromatic centers or color forming 
moieties under the specified experimental conditions. Moreover, upon photocatalysis a higher photocatalyst dose was more effective for the removal of both absorption centers. The most significant $\mathrm{UV}_{280} / \mathrm{Color}_{436}$ decrease was attained for $30 \mathrm{kDaHA}$ in the presence of $0.50 \mathrm{mg} / \mathrm{mL} \mathrm{Cu}-\mathrm{LF}$ contrary to the removal percentage of DOC (Tables 1 and 2).

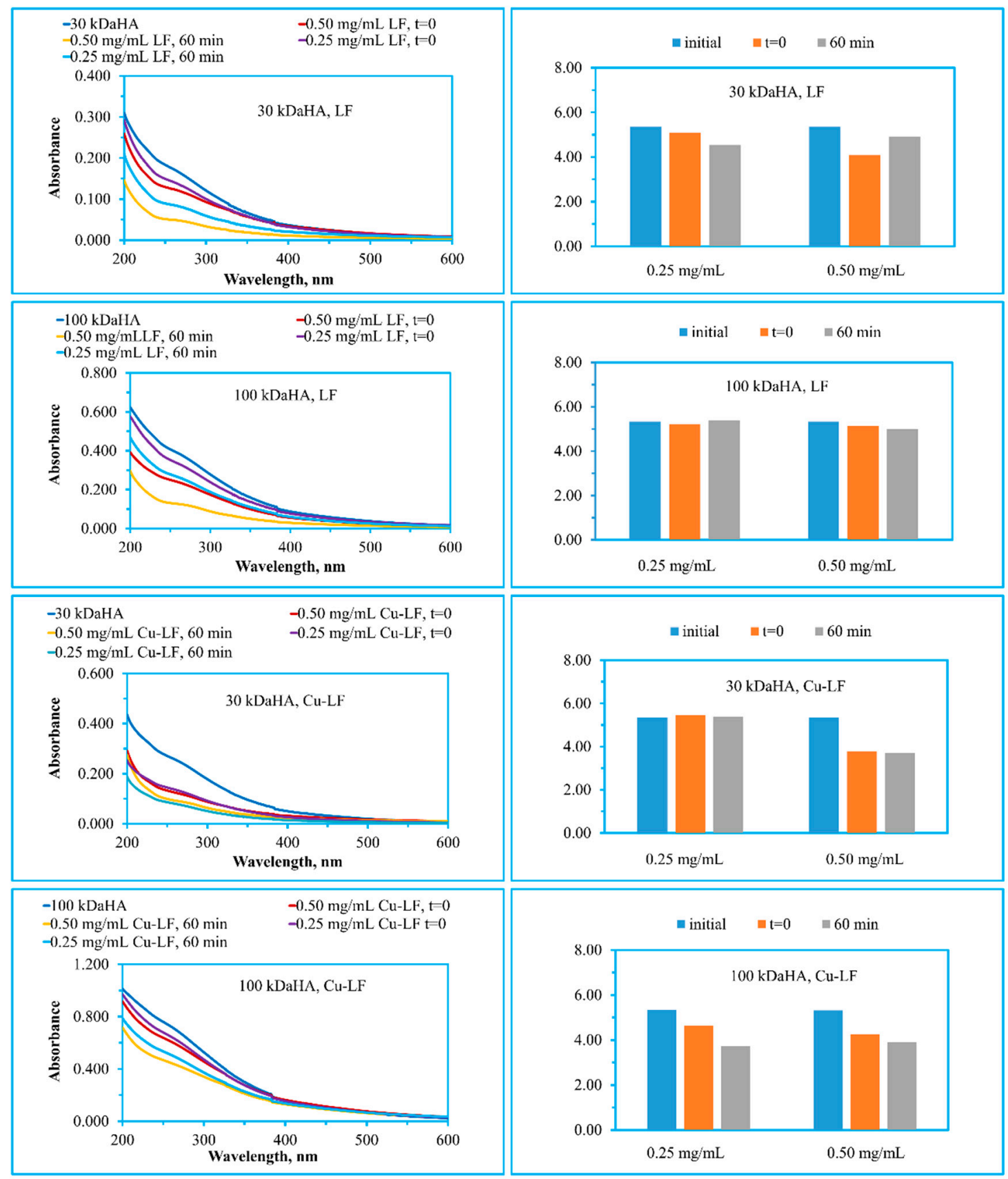

Figure 1. (UV-vis) absorption spectra (left column) and $\mathrm{UV}_{280} /$ Color $_{436}$ (right column) variations humic acid (HA) samples upon the use of an $\mathrm{LaFeO}_{3}$ (LF) specimen in comparison to Cu-LF, recorded for initial $t=0$ and $t=60$ min irradiation conditions.

Photocatalytic degradation kinetics of $30 \mathrm{kDaHA}$ using $0.25 \mathrm{mg} / \mathrm{mL} \mathrm{LF}$ as well as Cu-LF were modeled [40] by a pseudo first-order kinetic model $\left(R^{2}>0.80\right)$. Kinetic model parameters were discussed in a comparative manner with respect to the role of humic properties (Table 1). 
Table 1. Kinetic parameters of photocatalytic degradation of $30 \mathrm{kDaHA}$ sample using LF and Cu-LF, dose $0.25 \mathrm{mg} / \mathrm{mL}$.

\begin{tabular}{|c|c|c|c|c|c|c|c|c|c|c|}
\hline \multirow{2}{*}{$\begin{array}{l}\text { Photocatalyst } \\
\text { Specimen }\end{array}$} & \multicolumn{2}{|c|}{ Color $_{436}$} & \multicolumn{2}{|c|}{$\mathrm{UV}_{365}$} & \multicolumn{2}{|c|}{$\mathrm{UV}_{\mathbf{2 8 0}}$} & \multicolumn{2}{|c|}{$\mathrm{UV}_{254}$} & \multicolumn{2}{|c|}{ DOC } \\
\hline & $\begin{array}{c}\text { Rate } \\
\mathrm{m}^{-1} / \mathrm{min}\end{array}$ & $\mathbf{t}_{\frac{1}{2}} \min$ & $\begin{array}{c}\text { Rate } \\
\mathrm{m}^{-1} / \mathrm{min}\end{array}$ & $\mathbf{t}_{\frac{1}{2}} \min$ & $\begin{array}{c}\text { Rate } \\
\mathrm{m}^{-1 / \mathrm{min}}\end{array}$ & $\mathbf{t}_{\frac{1}{2}} \min$ & $\begin{array}{c}\text { Rate } \\
\mathrm{m}^{-1} / \mathrm{min}\end{array}$ & $\mathbf{t}_{\frac{1}{2}} \min$ & $\begin{array}{c}\text { Rate } \\
\mathbf{m}^{-1} / \mathrm{min}\end{array}$ & $\mathbf{t}_{\frac{1}{2}} \min$ \\
\hline LF & $2.2 \times 10^{-4}$ & 81 & $5.4 \times 10^{-4}$ & 64 & $1.4 \times 10^{-3}$ & 63 & $1.7 \times 10^{-3}$ & 60 & $3.0 \times 10^{-2}$ & 60 \\
\hline Cu-LF & $1.7 \times 10^{-3}$ & 34 & $2.4 \times 10^{-3}$ & 33 & $2.8 \times 10^{-3}$ & 35 & $5.1 \times 10^{-3}$ & 36 & $3.1 \times 10^{-2}$ & 77 \\
\hline
\end{tabular}

Table 2. Removal percentages of UV-vis parameters and DOC in relation to $\mathrm{CbUV}_{254}$ (carbon based $\mathrm{UV}_{254}$ ) and Fluorescence Index upon an irradiation period of $60 \mathrm{~min}$.

\begin{tabular}{|c|c|c|c|c|c|c|c|}
\hline \multirow{2}{*}{ Sample } & \multicolumn{5}{|c|}{ Removal \% } & \multirow{2}{*}{$\begin{array}{l}\mathrm{CbUV}_{254} \\
\mathrm{~L} / \mathrm{mg} \mathrm{m}\end{array}$} & \multirow{2}{*}{$\begin{array}{c}\text { Fluorescence } \\
\text { Index }\end{array}$} \\
\hline & Color $_{436}$ & $\mathrm{UV}_{365}$ & $\mathrm{UV}_{280}$ & $\mathrm{UV}_{254}$ & DOC & & \\
\hline 30 DaHA & - & - & - & - & - & 6.89 & 1.04 \\
\hline $\mathrm{LF}, 0.25 \mathrm{mg} / \mathrm{mL}$ & 40.8 & 47.8 & 49.7 & 51.0 & 54.5 & 7.44 & 1.12 \\
\hline $\mathrm{LF}, 0.50 \mathrm{mg} / \mathrm{mL}$ & 68.2 & 70.9 & 70.8 & 71.8 & 52.7 & 4.11 & 1.18 \\
\hline $\mathrm{Cu}-\mathrm{LF}, 0.25 \mathrm{mg} / \mathrm{mL}$ & 70.2 & 72.5 & 70.0 & 68.4 & 56.3 & 3.03 & 1.36 \\
\hline $\mathrm{Cu}-\mathrm{LF}, 0.50 \mathrm{mg} / \mathrm{mL}$ & 47.9 & 58.9 & 63.4 & 63.8 & 37.5 & 1.73 & 1.17 \\
\hline 100 kDaHA & - & - & - & - & - & 9.47 & 0.992 \\
\hline $\mathrm{LF}, 0.25 \mathrm{mg} / \mathrm{mL}$ & 32.7 & 31.0 & 32.0 & 31.6 & 26.2 & 12.4 & 1.06 \\
\hline $\mathrm{LF}, 0.50 \mathrm{mg} / \mathrm{mL}$ & 64.6 & 68.4 & 66.8 & 67.6 & 43.8 & 7.70 & 1.10 \\
\hline $\mathrm{Cu}-\mathrm{LF}, 0.25 \mathrm{mg} / \mathrm{mL}$ & 10.8 & 22.7 & 30.0 & 30.0 & 45.3 & 12.1 & 1.08 \\
\hline $\mathrm{Cu}-\mathrm{LF}, 0.50 \mathrm{mg} / \mathrm{mL}$ & 14.6 & 28.1 & 37.4 & 38.5 & 38.2 & 9.41 & 1.11 \\
\hline
\end{tabular}

The use of an LF catalyst with $0.25 \mathrm{mg} / \mathrm{mL}$ for the removal of $30 \mathrm{kDaHA}$ presented an order of $\mathrm{k}$ as follows: $8.54 \times 10^{-3} \mathrm{Color}_{436}, 1.08 \times 10^{-2} \mathrm{UV}_{365}, 1.10 \times 10^{-2} \mathrm{UV}_{280}$, and $1.16 \times 10^{-2} \mathrm{UV}_{254}$ in comparison to DOC removal $1.17 \times 10^{-2} \mathrm{~min}^{-1}$. Half-life $\left(\mathrm{t}_{1 / 2}, \mathrm{~min}\right)$ values displayed the same order as Color $436, \mathrm{UV}_{365}, \mathrm{UV}_{280}$, and $\mathrm{UV}_{254}$. However, a similar trend could not be assessed for Cu-LF specimens under solar light simulated conditions. The removal of $30 \mathrm{kDaHA}$ in the presence of $\mathrm{Cu}-\mathrm{LF}$ resulted in the following values of the kinetic constant: $2.05 \times 10^{-2}$ Color $_{436}, 2.13 \times 10^{-2} \mathrm{UV}_{365}$, $1.96 \times 10^{-2} \mathrm{UV}_{280}$, and $1.92 \times 10^{-2} \mathrm{~min}^{-1} \mathrm{UV}_{254}$. Degradation rate constants expressed a decreasing order as $\mathrm{UV}_{365}>\mathrm{Color}_{436}>\mathrm{UV}_{280}>\mathrm{UV}_{254}$, whereas DOC removal was attained as $9.05 \times 10^{-3} \mathrm{~min}^{-1}$. As expected, half-life values followed the same trend. Both color forming moieties and UV absorbing centers were removed concomitantly in the case of $\mathrm{Cu}-\mathrm{LF}$, whereas upon the use of LF UV absorbing centers were removed preferentially.

Table 2 summarizes the removal percentages of the UV-vis parameters and DOC as well as $\mathrm{CbUV}_{254}$ and the Fluorescence Index. After $60 \mathrm{~min}$ of simulated solar irradiation, the resulting DOC content was sufficient to enable UV-vis and fluorescence measurements. A fast DOC removal of $30 \mathrm{kDaHA}$ was reached with $0.25 \mathrm{mg} / \mathrm{mL} \mathrm{Cu}-\mathrm{LF}$ and considerably slower removal upon use of $0.50 \mathrm{mg} / \mathrm{mL}$ of $\mathrm{Cu}-\mathrm{LF}$. For $100 \mathrm{kDaHA}$, the best performance was achieved using $0.25 \mathrm{mg} / \mathrm{mL} \mathrm{Cu}-\mathrm{LF}$. The highest mineralization was achieved for $30 \mathrm{kDaHA}$ upon use of $0.25 \mathrm{mg} / \mathrm{mL} \mathrm{Cu}-\mathrm{LF}$ whereas lowest mineralization was attained for $100 \mathrm{kDaHA}$ upon use of $0.25 \mathrm{mg} / \mathrm{mL} \mathrm{LF}$.

Removal percentages could also be compared to the dose dependent exposed surface area of LF and $\mathrm{Cu}-\mathrm{LF}$ (Figure 2). The DOC parameter was selected under initial exposure $\left(\mathrm{DOC}_{\mathrm{ads}}, \mathrm{t}=0\right)$ and following treatment $\left(D C_{\text {rem }}, t_{i r r}=60 \mathrm{~min}\right)$ conditions. Since the surface areas of $L F\left(13 \mathrm{~m}^{2} / \mathrm{g}\right)$ and $\mathrm{Cu}-\mathrm{LF}\left(16 \mathrm{~m}^{2} / \mathrm{g}\right)$ were not significantly different from each other, extensive surface coverage were not expected for either of the photocatalyst specimens and HA samples prior to initiation of light exposure. Incremental increase of exposed surface area could not be directly related to the initial adsorption of DOC for both of the photocatalyst specimens and HA samples. It could be indicated that surface attractions could be most probably occurring via different reaction pathways due to the presence and absence of $\mathrm{Cu}$ dopant. On the other hand, the presence of the higher molecular size fraction of HA (100 kDaHA) displayed a more influential effect on mineralization of organic content with increasing surface area of $\mathrm{Cu}-\mathrm{LF}$ in comparison to $\mathrm{LF}$. 


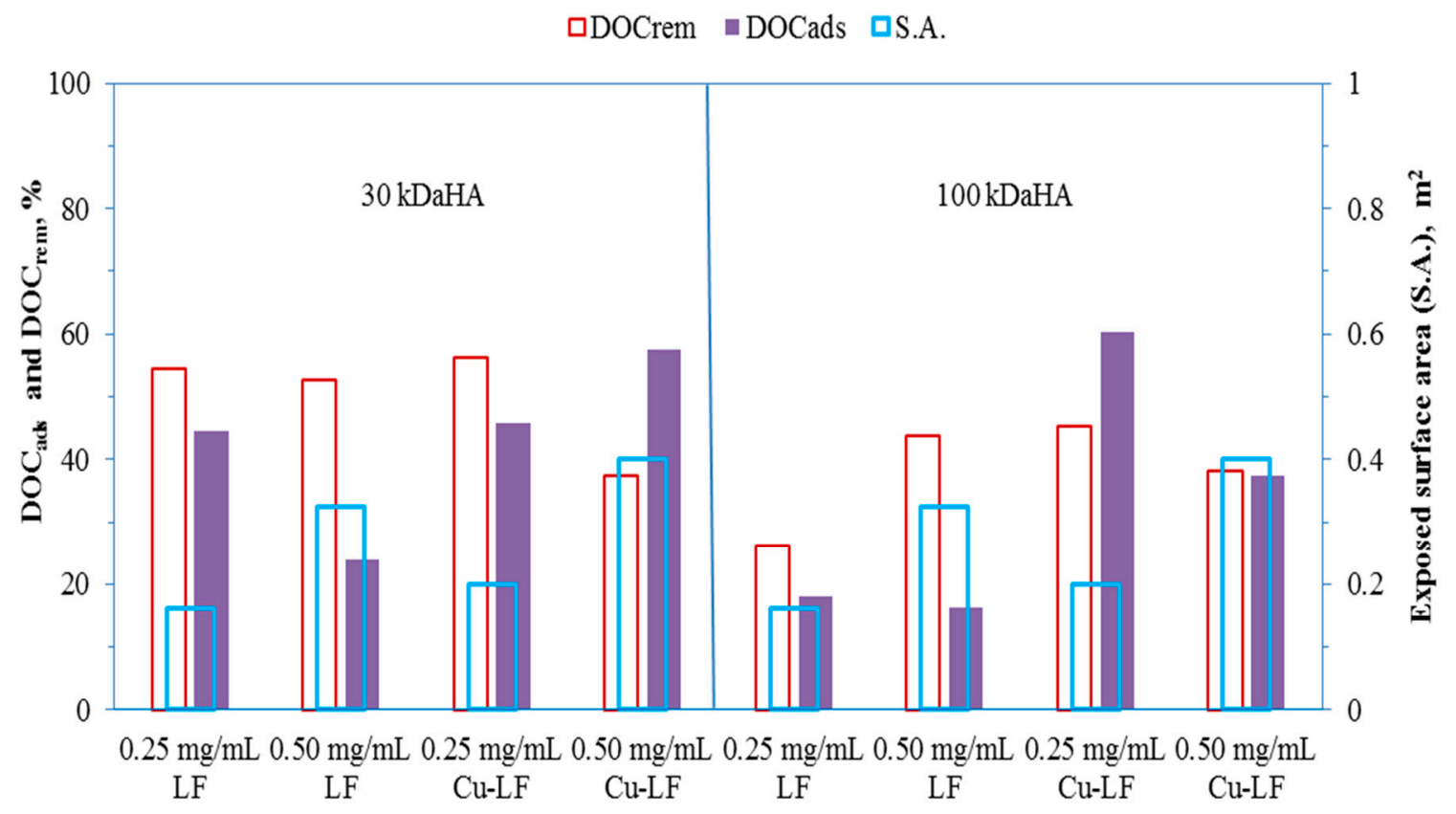

Figure 2. Dose dependent $\mathrm{DOC}_{\mathrm{ads}}$ and $\mathrm{DOC}_{\mathrm{rem}}$ in comparison to exposed surface area (S.A).

Since $\mathrm{UV}_{254}$ was regarded as a surrogate parameter of DOC, the carbon based parameter $\left(\mathrm{CbUV}_{254}\right)$ could be used for the assessment of simultaneous removal of UV absorbing aromatic centers in accordance with mineralization efficiency [9]. $30 \mathrm{kDaHA}$ expressed a decreasing tendency of aromaticity $\left(\mathrm{CbUV}_{254}<4\right)$ upon the use of both LF and Cu-LF specimens excluding a lower dose as $0.25 \mathrm{mg} / \mathrm{mL}$ LF. However, $100 \mathrm{kDaHA}$ retained an organic matrix composition expressing aromaticity as $\mathrm{CbUV}_{254}>4$. Furthermore, the data did not impress a significant correlation between $\mathrm{UV}_{254}$ and DOC removals as attained upon the use of $\mathrm{TiO}_{2}$ [9]. Moreover, no significant correlation could be attained for $\mathrm{CbColor}_{436}, \mathrm{CbUV}_{365}$, and $\mathrm{CbUV}_{280}$ parameters with the DOC removal efficiencies. These results indicated that the diverse and complex nature of the humic subgroups present in different molecular size fractions could possibly lead to various surface interactions during the course of the degradation reactions under oxidative conditions. FI did not significantly change under all experimental conditions revealing the simultaneous removal of humic and fulvic like fluorophoric centers within the humic matter as will be further addressed by EEM contour plots. The effect due to the extended irradiation periods at $90 \mathrm{~min}$ and $120 \mathrm{~min}$ resulted in an enhancement of DOC removal efficiencies being more significant in Cu-LF specimens as $\leq 10 \%$ in comparison to LF upon use of $30 \mathrm{kDaHA}$.

Photocatalyst stability was assessed through leaching experiments under the specified experimental conditions as $\mathrm{t}=0$ and under solar light in the absence of humic acid. No significant amount of $\mathrm{Fe}, \mathrm{Cu}$, and $\mathrm{La}$ was determined with respect to the lowest limit of quantification values as $\mathrm{Fe}=0.05 \mathrm{mg} / \mathrm{L} ; \mathrm{Cu}=0.03 \mathrm{mg} / \mathrm{L} ; \mathrm{La}=0.1 \mathrm{mg} / \mathrm{L}$. Only a slight increase in nitrate $(<0.03 \mathrm{mg} / \mathrm{L})$ was observed. The reason could be attributed to the usage amount of $\mathrm{Fe}\left(\mathrm{NO}_{3}\right)_{3} \cdot 9 \mathrm{H}_{2} \mathrm{O}$ for the preparation of LF.

\subsection{EEM Fluorescence Properties}

Use of EEM fluorescence contour plots has been shown to be a versatile tool for visualization of the removal of humic-like and fulvic like fluorophores and formation of fragmentation products [37,41]. Depending on the excitation-emission wavelength regions, five regions were ascribed as (i) Region I: Aromatic Proteins I ( $\lambda_{\text {exc }} 220-250$ and $\left.\lambda_{\text {emis }} 280-332\right)$, (ii) Region II: Aromatic Proteins II ( $\lambda_{\text {exc }} 220-250$ and $\lambda_{\text {emis }} 332-380$ ), (iii) Region III: Fulvic-like ( $\lambda_{\text {exc }} 220-250$ and $\lambda_{\text {emis }} 380-580$ ), (iv) Region IV: Microbial by-products ( $\lambda_{\text {exc }} 250-470$ and $\lambda_{\text {emis }} 280-380$ ), and (v) Region V: Humic-like ( $\lambda_{\text {exc }} 250-470$ and $\lambda_{\text {emis }}$ 
380-580). EEM fluorescence matrix contour plots of humic acids under initial, initial adsorption and following treatment for an irradiation period of $60 \mathrm{~min}$ were presented (Figures 3 and 4). From a general perspective, EEM fluorescence plots of humic acid upon treatment by using LF and Cu-LF mainly indicated the presence of humic-like and fulvic-like fluorophores under all conditions.

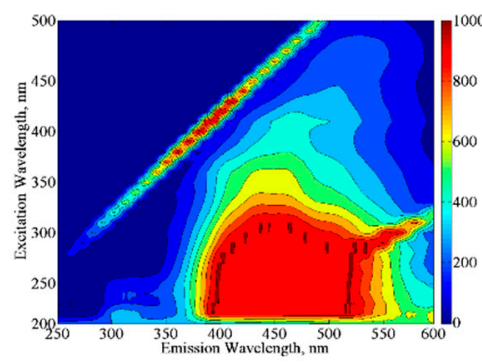

30 kDaHA

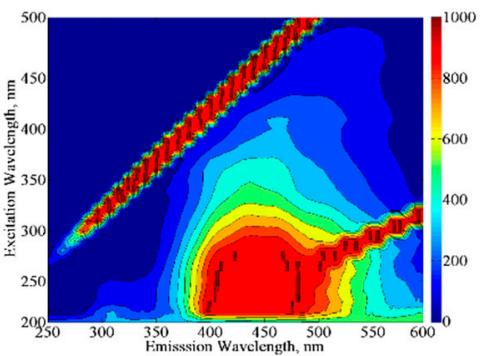

$\mathrm{t}=0, \mathrm{LF}, 0.25 \mathrm{mg} / \mathrm{mL}$

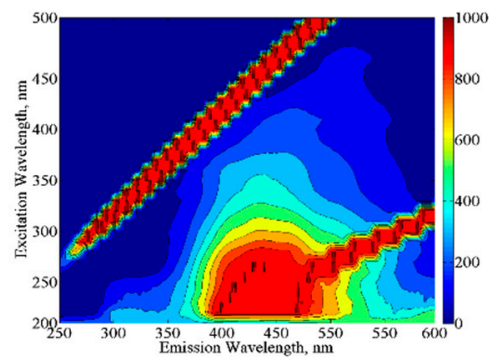

$\mathrm{t}=\mathbf{0}, \mathrm{LF}, \mathbf{0 . 5 0} \mathrm{mg} / \mathrm{mL}$

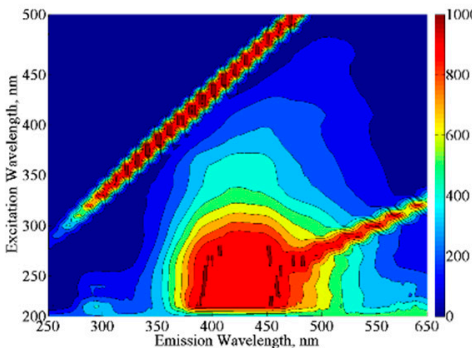

$\mathrm{t}=\mathbf{0}, \mathrm{Cu}-\mathrm{LF}, 0.25 \mathrm{mg} / \mathrm{mL}$

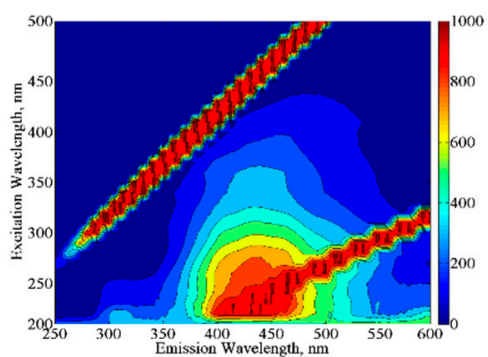

$\mathrm{t}=\mathbf{0}, \mathrm{Cu}-\mathrm{LF}, \mathbf{0 . 5 0} \mathrm{mg} / \mathrm{mL}$

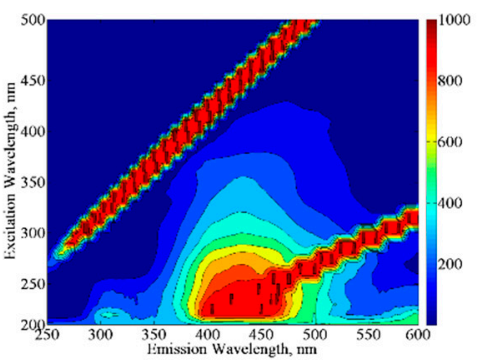

$\mathrm{t}=60, \mathrm{LF}, 0.25 \mathrm{mg} / \mathrm{mL}$

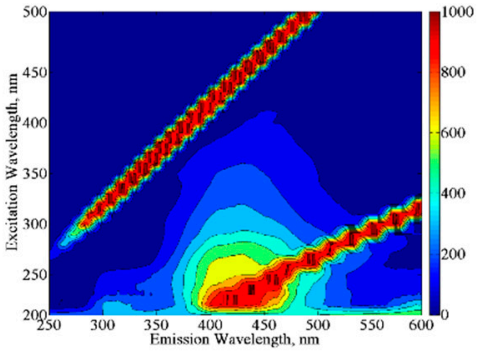

$\mathrm{t}=60, \mathbf{L F}, 0.50 \mathrm{mg} / \mathrm{mL}$

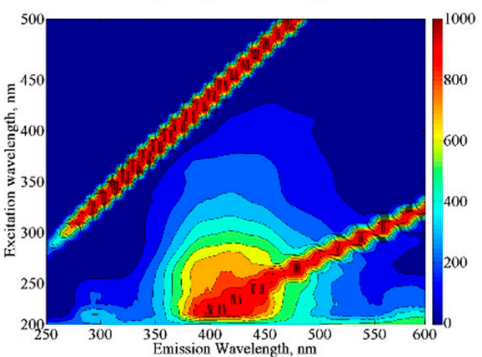

$\mathrm{t}=60, \mathrm{Cu}-\mathrm{LF}, 0.25 \mathrm{mg} / \mathrm{mL}$

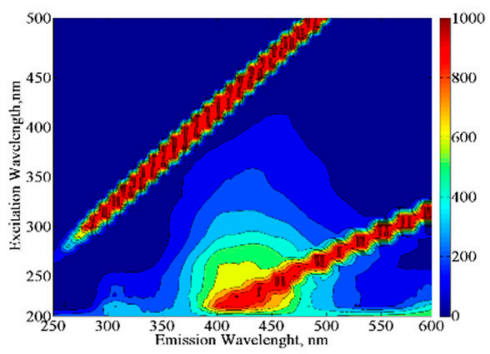

$\mathrm{t}=60, \mathrm{Cu}-\mathrm{LF}, 0.50 \mathrm{mg} / \mathrm{mL}$

Figure 3. EEM fluorescence contour plots of $30 \mathrm{kDaHA}$ upon use of LF and Cu-LF. 


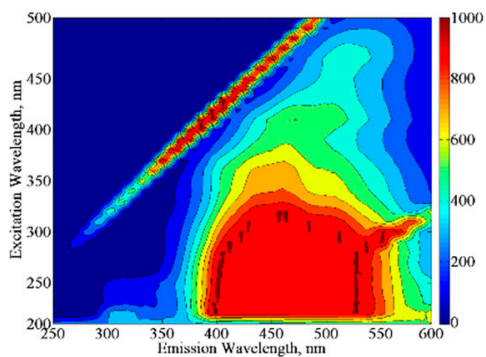

100 kDaHA

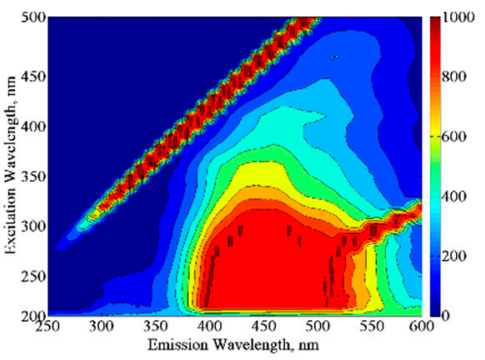

$\mathrm{t}=\mathbf{0}, \mathrm{LF}, 0.25 \mathrm{mg} / \mathrm{mL}$

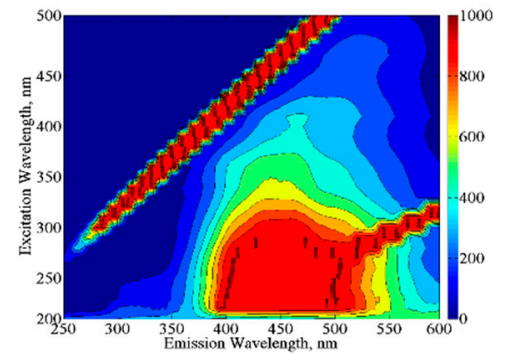

$\mathrm{t}=\mathbf{0}, \mathrm{LF}, 0.50 \mathrm{mg} / \mathrm{mL}$

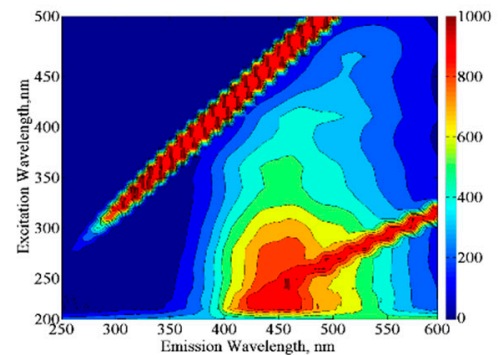

$\mathrm{t}=\mathbf{0}, \mathrm{Cu}-\mathrm{LF}, 0.25 \mathrm{mg} / \mathrm{mL}$

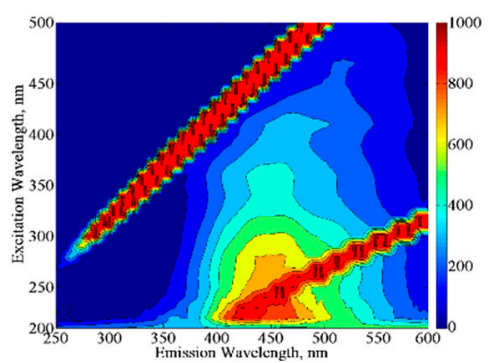

$\mathrm{t}=\mathbf{0}, \mathrm{Cu}-\mathrm{LF}, 0.50 \mathrm{mg} / \mathrm{mL}$

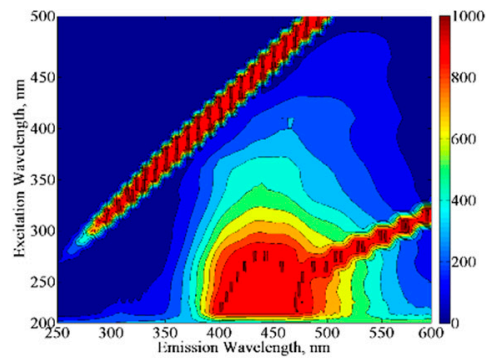

$\mathrm{t}=60, \mathrm{LF}, 0.25 \mathrm{mg} / \mathrm{mL}$

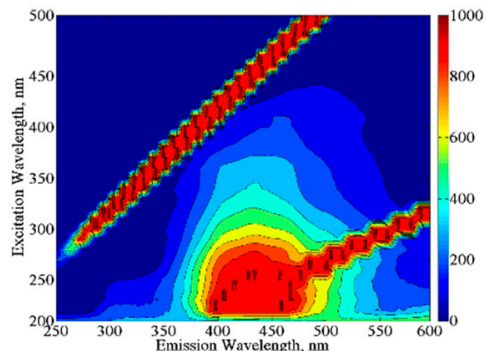

$\mathrm{t}=60, \mathrm{LF}, 0.50 \mathrm{mg} / \mathrm{mL}$

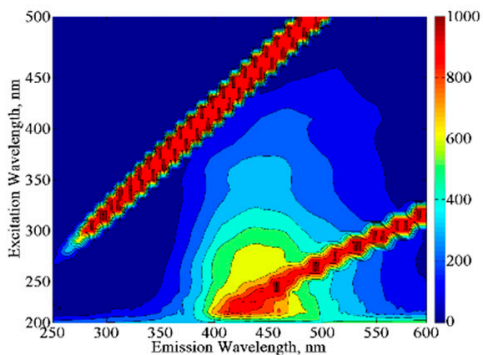

$\mathrm{t}=60, \mathrm{Cu}-\mathrm{LF}, 0.25 \mathrm{mg} / \mathrm{mL}$

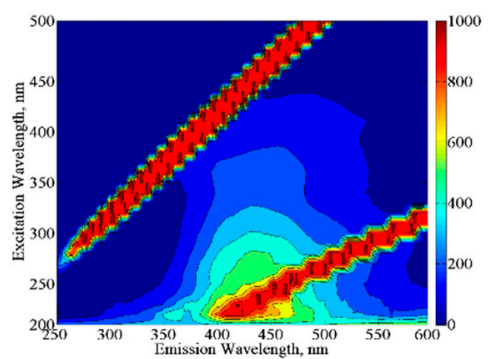

$\mathrm{t}=60, \mathrm{Cu}-\mathrm{LF}, 0.50 \mathrm{mg} / \mathrm{mL}$

Figure 4. Excitation-emission matrix (EEM) fluorescence contour plots of $100 \mathrm{kDaHA}$ upon use of LF and $\mathrm{Cu}-\mathrm{LF}$.

In the presence of $30 \mathrm{kDaHA}$ and $0.25 \mathrm{mg} / \mathrm{mL}$ photocatalyst, initial adsorptive interactions $(t=0)$ onto either LF or Cu-LF resulted in slight variations in regional speciation of fluorophores. Following photocatalysis ( $t_{\text {irr }}=60 \mathrm{~min}$ ), subsequent to successive removal of all fluorophoric groups, no significant variation in regional distribution could be observed. An increasing photocatalyst dose to $0.50 \mathrm{mg} / \mathrm{mL}$ resulted in the removal of both humic-like and fulvic like fluorophores in accordance with $\mathrm{UV}_{254}$ and DOC removals. This effect was more pronounced in the case of $\mathrm{Cu}-\mathrm{LF}$ in comparison to LF. No further shift to other fluorophoric groups composed of aromatic proteins as well as microbial by-products could be observed.

In the presence of $100 \mathrm{kDaHA}$ and $0.25 \mathrm{mg} / \mathrm{mL}$ photocatalyst, initial adsorptive interactions $(t=0)$ onto Cu-LF was significantly different in comparison to LF. Doubling the photocatalyst dose to $0.50 \mathrm{mg} / \mathrm{mL}$ resulted in removal of fulvic-like fluorophores more significantly. This trend was found to be consistent for an irradiation period of $60 \mathrm{~min}$. In a similar fashion, presence of other 
fluorophoric groups composed of aromatic proteins (Regions I and II) as well as microbial by-products (Region IV) could not be observed upon irradiation period of $60 \mathrm{~min}$. The reason could be attributed to concomitant removal of humic-like and fulvic-like fluorophores via mineralization. It should also be mentioned that $100 \mathrm{kDaHA}$ exhibited higher $\mathrm{UV}_{254}$ and DOC contents in comparison to $30 \mathrm{kDaHA}$. Role of $\mathrm{Cu}$-doping was more significant irrespecitve of the applied dose during photoatalysis.

From a general perspective [41], upon oxidative treatment of humic acids through degradation and fragmentation along with a shift to lower molecular size fractions, simultaneous removal of all molecular size fractions could also be expected [42]. The resultant organic matrix could retain fractions expressing major fluorophoric regions. Since no leaching of $\mathrm{La}$, $\mathrm{Fe}$ or $\mathrm{Cu}$ was observed, decrease in fluorescence intensities could not be related to the fluorescence quenching due to metal complexation.

\section{Materials and Methods}

\subsection{Materials and Analytical Methodology}

HA was purchased from Aldrich (Sigma-Aldrich, St. Louis, MO, USA) as sodium salt and the $50 \mathrm{mg} / \mathrm{L}$ stock solution was prepared in ultra-pure water $\left(18.2 \mathrm{M} \Omega \mathrm{cm}\right.$ at $\left.25^{\circ} \mathrm{C}\right) .100 \mathrm{kDa}(100 \mathrm{kDaHA})$ and $30 \mathrm{kDa}(30 \mathrm{kDaHA})$ molecular size fractions were prepared by filtration through $0.45 \mu \mathrm{m}$ cellulose acetate membrane filter (Millipore) followed by ultrafiltration process using Amicon 8050 ultrafiltration stirred cell unit (EMD Millipore Corporation, Billerica, MA, USA) using membrane filters with $100 \mathrm{kDa}$ and $30 \mathrm{kDa}$ cut-offs [36]

Organic matrix characterized by dissolved organic carbon contents (DOC, $\mathrm{mg} / \mathrm{L}$ ) was determined as non-purgeable organic carbon using Total Organic Carbon Analyzer Shimadzu TOC VWP (Kyoto, Japan). Calibration was done by using potassium hydrogen phthalate (99.95\%, Sigma-Aldrich, St. Louis, MO, USA) in low range as $0-20 \mathrm{mgOrgC} / \mathrm{L}\left(\mathrm{R}^{2}>0.99\right)$.

UV-vis spectroscopic measurements were performed using Perkin Elmer Lambda 35 UV-vis double beam spectrophotometer (Waltham, MA, USA) employing quartz cuvettes of $1.0 \mathrm{~cm}$ optical path length in the wavelength range of 200-600 nm and expressed as absorbance values $\left(\mathrm{cm}^{-1}\right)$ at specified wavelengths of $436 \mathrm{~nm}$ (Color 436$), 365 \mathrm{~nm}\left(\mathrm{UV}_{365}\right), 280 \mathrm{~nm}\left(\mathrm{UV}_{280}\right)$, and $254 \mathrm{~nm}\left(\mathrm{UV}_{254}\right)$. Specific absorbance ratio as $\mathrm{UV}_{280} / \mathrm{Color}_{436}$ and carbon based spectroscopic parameters as $\mathrm{CbColor}_{436}$, $\mathrm{CbUV}_{365}, \mathrm{CbUV}_{280}$, and $\mathrm{CbUV}_{254}(\mathrm{~L} / \mathrm{mg} \mathrm{m})$ were presented $[38,43]$.

Fluorescence spectroscopic measurements were carried on Perkin Elmer LS 55 Luminescence Spectrometer (Waltham, MA, USA) equipped with a $150 \mathrm{~W}$ Xenon arc lamp using quartz cell. Three-dimensional excitation-emission matrix (EEM) contour plots were created by plotting fluorescence intensity as a function of emission (x-axis) and excitation (y-axis) wavelengths using Matlab R2013a. Fluorescence index (FI) was expressed as the ratio of the emission intensity at $\lambda_{\text {emis }}$ $450 \mathrm{~nm}$ to that at $\lambda_{\text {emis }} 500 \mathrm{~nm}$, following excitation at $\lambda_{\text {exc }} 370 \mathrm{~nm}$ [3]

Lanthanum ferrite $\mathrm{LaFeO}_{3}(\mathrm{LF})$ and $\mathrm{Cu}$ doped $\mathrm{LF}$ as $\mathrm{LaFe}_{0.90} \mathrm{Cu}_{0.10} \mathrm{O}_{3-\delta}(\mathrm{Cu}-\mathrm{LF})$ were prepared by citrate autocombustion method [15].

Leaching of La, Fe, and $\mathrm{Cu}$ was followed by ICP-OES (Perkin Elmer Optima 2100DV ICP-OES, Waltham, MA, USA). Anion contents (chloride, nitrite, nitrate, sulfate and phosphate) were determined by using an ion chromatography (DIONEX ICX-3000).

\subsection{Photocatalytic Degradation Experiments}

Photocatalytic degradation experiments were carried out using an ATLAS Suntest CPS+ simulator (Atlas, IL, USA) equipped with an air cooled Xenon lamp $\left(250 \mathrm{~W} / \mathrm{m}^{2}\right.$ and wavelength range of 300-800 nm) as the light source (Ref. 56052371, Atlas CPS+ Solar Simulator). The $50 \mathrm{~mL} 30 \mathrm{kDaHA}$ and $100 \mathrm{kDaHA}$ samples were subjected to photocatalytic degradation in the presence of 0.25 and $0.50 \mathrm{mg} / \mathrm{mL}$ doses. Photocatalyst dose was selected considering the expected extent of initial adsorption $(t=0)$ of humic sub-fractions onto the photocatalyst surface. Since $30 \mathrm{kDa}$ and $100 \mathrm{kDa}$ humic molecular size fractions are comprised of various sub-fractions displaying diverse functional 
groups that could be deprotonated depending on the $\mathrm{pH}$ of the reaction medium, different adsorption behaviors could be expected (as explained in Section 2.1). Moreover, $\mathrm{pH}$ of the reaction was not changed, neither to acidic (coiled/ condensed) nor to alkaline (extended/linear), since humic molecular size fractions might express different conformational orientations. Therefore, reaction conditions would change in an uncontrollable manner that could also lead to meaningless comparisons. Initial adsorption of humic fractions was determined upon instantaneous introduction onto photocatalyst specimen $(t=0$ condition) and no further dark interaction was attained upon prolonged exposure periods. Photocatalytic experiments were performed for irradiation period of 0-120 min with 10 min intervals. Samples were subjected filtration through $0.45 \mu \mathrm{m}$ membrane filter prior to all analysis.

\section{Conclusions}

This study was performed to investigate the photocatalytic performance of novel photocatalysts i.e., $\mathrm{LaFeO}_{3}$ perovskite (LF) and copper lanthanum ferrite (Cu-LF). Based on the presented data, photocatalytic degradation kinetics indicated the possible use of LF and $\mathrm{Cu}-\mathrm{LF}$ for the degradation of humic acids as the model compound of DOM. Furthermore, the dose effect of the respective LF and $\mathrm{Cu}-\mathrm{LF}$ specimens could be related to the surface interactions in relation to the presence of the organic matter contents expressed by different molecular size fractions. Highest mineralization was achieved upon use of photocatalyst dose as $0.25 \mathrm{mg} / \mathrm{mL}$ of $\mathrm{Cu}-\mathrm{LF}$ for $30 \mathrm{kDaHA}$, whereas lowest mineralization was attained for $100 \mathrm{kDaHA}$ upon use of LF. Following photocatalytic degradation of humic matter, organic matrix was further characterized by EEM fluorescence contour plots. Upon exposure to solar irradiation for $60 \mathrm{~min}$, organic matrix retained humic-like and fulvic-like fluorophores excluding the formation of new fluorophoric groups that could signify destructive fragmentation products via photocatalysis. It could be emphasized that humic acids are comprised of complex and polydisperse organic compounds with undefined molecular structures; therefore, the attained results holds prime importance in comparison to the simple compounds that are used as models for activity testing. This study brings significant baseline information on the successful utilization of non- $\mathrm{TiO}_{2}$ photocatalysts for degradation of refractory organic compounds present in natural waters as well as wastewaters upon solar light exposure.

Author Contributions: I.N.S. and M.B. conceived and designed the experiments; I.N.S., A.T., and N.T. performed the experiments; I.N.S., N.T., and M.B. analyzed the data; I.N.S., N.T., and M.B. wrote the paper.

Funding: Financial support, provided by Research Fund of the Bogazici University through Project No: 13381, and the University of Bergamo, is gratefully acknowledged.

Conflicts of Interest: The authors declare no conflict of interest.

\section{References}

1. Aiken, G.R.; McKnight, D.M.; Wershaw, R.L.; MacCarthy, P. Humic substances in soil, sediment and water: Geochemistry, isolation and characterization. Geol. J. 1986, 21, 213-221.

2. Huang, P.M.; Hardie, A.G. Formation mechanisms of humic substances in the environment. In Biophysico-Chemical Processes Involving Natural Nonliving Organic Matter in Environmental Systems, 1st ed.; Senesi, N., Xing, B., Huang, P.M., Eds.; John Wiley \& Sons, Inc.: Hoboken, NJ, USA, 2009; pp. 41-109. ISBN 9780470413005.

3. Birben, N.C.; Paganini, M.C.; Calza, P.; Bekbolet, M. Photocatalytic degradation of humic acid using a novel photocatalyst: Ce-doped ZnO. Photochem. Photobiol. Sci. 2017, 16, 24-30. [CrossRef]

4. Birben, N.C.; Uyguner-Demirel, C.S.; Kavurmaci, S.S.; Gürkan, Y.Y.; Turkten, N.; Cinar, Z.; Bekbolet, M. Application of Fe-doped $\mathrm{TiO}_{2}$ specimens for the solar photocatalytic degradation of humic acid. Catal. Today 2017, 281, 78-84. [CrossRef]

5. Birben, N.C.; Uyguner-Demirel, C.S.; Sen-Kavurmaci, S.; Gurkan, Y.Y.; Turkten, N.; Cinar, Z.; Bekbolet, M. Comparative evaluation of anion doped photocatalysts on the mineralization and decolorization of natural organic matter. Catal. Today 2015, 240, 125-131. [CrossRef] 
6. Uyguner, C.S.; Bekbolet, M. Photocatalytic degradation of natural organic matter: Kinetic considerations and light intensity dependence. Int. J. Photoenergy 2004, 6, 73-80. [CrossRef]

7. Uyguner, C.S.; Bekbolet, M. Aqueous photocatalysis, natural organic matter characterization and removal: A case study of the photacatalytic oxidation of fulvic acid. In Dangerous Pollutants (Xenobiotics) in Urban Water Cycle. NATO Science for Peace and Security Series, 1st ed.; Hlavinek, P., Bonacci, O., Marsalek, J., Mahrikova, I., Eds.; Springer: Dordrecht, The Netherlands, 2008; pp. 247-257. ISBN 978-1-4020-6800-3.

8. Uyguner, C.S.; Bekbolet, M. Evaluation of humic acid photocatalytic degradation by UV-vis and fluorescence spectroscopy. Catal. Today 2005, 101, 267-274. [CrossRef]

9. Uyguner-Demirel, C.S.; Bekbolet, M. Significance of analytical parameters for the understanding of natural organic matter in relation to photocatalytic oxidation. Chemosphere 2011, 84, 1009-1031. [CrossRef]

10. Anpo, M.; Takeuchi, M. Design and development of second-generation titanium oxide photocatalysts to better our environment-approaches in realizing the use of visible light. Int. J. Photoenergy 2001, 3, 89-94. [CrossRef]

11. Byrne, C.; Subramanian, G.; Pillai, S.C. Recent advances in photocatalysis for environmental applications. J. Environ. Chem. Eng. 2018, 6, 3531-3555. [CrossRef]

12. Kanhere, P.; Chen, Z. A review on visible light active perovskite-based photocatalysts. Molecules 2014, 19, 19995-20022. [CrossRef]

13. Dai, X.P.; Wu, Q.; Li, R.J.; Yu, C.C.; Hao, Z.P. Hydrogen production from a combination of the water-gas shift and redox cycle process of methane partial oxidation via lattice oxygen over $\mathrm{LaFeO}_{3}$ perovskite catalyst. J. Phys. Chem. B 2006, 110, 25856-25862. [CrossRef]

14. Wei, Z.-X.; Xu, Y.-Q.; Liu, H.-Y.; Hu, C.-W. Preparation and catalytic activities of $\mathrm{LaFeO}_{3}$ and $\mathrm{Fe}_{2} \mathrm{O}_{3}$ for $\mathrm{hmx}$ thermal decomposition. J. Hazard. Mater. 2009, 165, 1056-1061. [CrossRef]

15. Caronna, T.; Fontana, F.; Sora, I.N.; Pelosato, R. Chemical synthesis and structural characterization of the substitution compound $\mathrm{LaFe}_{1-\mathrm{x}} \mathrm{Cu}_{\mathrm{x}} \mathrm{O}_{3}(\mathrm{x}=0-0.40)$. Mater. Chem. Phys. 2009, 116, 645-648. [CrossRef]

16. Cavalieri, A.; Caronna, T.; Natali Sora, I.; Tulliani, J.M. Electrical characterization of room temperature humidity sensors in $\mathrm{La}_{0.8} \mathrm{Sr}_{0.2} \mathrm{Fe}_{1-\mathrm{x}} \mathrm{Cu}_{\mathrm{x}} \mathrm{O}_{3}(\mathrm{x}=0,0.05,0.10)$. Ceram. Int. 2012, 38, 2865-2872. [CrossRef]

17. Mancini, A.; Felice, V.; Natali Sora, I.; Malavasi, L.; Tealdi, C. Chemical compatibility study of melilite-type gallate solid electrolyte with different cathode materials. J. Solid State Chem. 2014, 213, 287-292. [CrossRef]

18. Natali Sora, I.; Caronna, T.; Fontana, F.; de Julián Fernández, C.; Caneschi, A.; Green, M. Crystal structures and magnetic properties of strontium and copper doped lanthanum ferrites. J. Solid State Chem. 2012, 191, 33-39. [CrossRef]

19. Natali Sora, I.; Felice, V.; Zurlo, F.; Licoccia, S.; Di Bartolomeo, E. Characterization of tantalum doped lanthanum strontium ferrite as cathode materials for solid oxide fuel cells. J. Alloys Compd. 2015, 648, 154-159. [CrossRef]

20. Natali Sora, I.; Fontana, F.; Passalacqua, R.; Ampelli, C.; Perathoner, S.; Centi, G.; Parrino, F.; Palmisano, L. Photoelectrochemical properties of doped lanthanum orthoferrites. Electrochimica Acta 2013, 109, 710-715. [CrossRef]

21. Parrino, F.; García-López, E.; Marcì, G.; Palmisano, L.; Felice, V.; Sora, I.N.; Armelao, L. Cu-substituted lanthanum ferrite perovskites: Preparation, characterization and photocatalytic activity in gas-solid regime under simulated solar light irradiation. J. Alloys Compd. 2016, 682, 686-694. [CrossRef]

22. Rosa, R.; Ponzoni, C.; Veronesi, P.; Natali Sora, I.; Felice, V.; Leonelli, C. Solution combustion synthesis of $\mathrm{La}_{1-x} \mathrm{Sr}_{\mathrm{x}} \mathrm{Fe}_{1-\mathrm{y}} \mathrm{Cu}_{\mathrm{y}} \mathrm{O}_{3} \pm \mathrm{w}(\mathrm{x}=0,0.2 ; \mathrm{y}=0,0.2)$ perovskite nanoparticles: Conventional vs. Microwaves ignition. Ceram. Int. 2015, 41, 7803-7810. [CrossRef]

23. Tulliani, J.-M.; Borgna, M.; Grigioni, I.; Sora, I.N. Microstructural study of aged ferrite powders for sensing layers. Ceram. Int. 2013, 39, 4923-4927. [CrossRef]

24. Zurlo, F.; Di Bartolomeo, E.; D’Epifanio, A.; Felice, V.; Natali Sora, I.; Tortora, L.; Licoccia, S. $\mathrm{La}_{0.8} \mathrm{Sr}_{0.2} \mathrm{Fe}_{0.8} \mathrm{Cu}_{0.2} \mathrm{O}_{3-\delta}$ as "cobalt-free" cathode for $\mathrm{La}_{0.8} \mathrm{Sr}_{0.2} \mathrm{Ga}_{0.8} \mathrm{Mg}_{0.2} \mathrm{O}_{3-\delta}$ electrolyte. J. Power Sources 2014, 271, 187-194. [CrossRef]

25. Zurlo, F.; Natali Sora, I.; Felice, V.; Luisetto, I.; D’Ottavi, C.; Licoccia, S.; Di Bartolomeo, E. Copper-doped lanthanum ferrites for symmetric SOFCs. Acta Mater. 2016, 112, 77-83. [CrossRef]

26. Natali Sora, I.; Fumagalli, D. Fast photocatalytic degradation of pharmaceutical micropollutants and ecotoxicological effects. Environ. Sci. Pollut. R. 2017, 24, 12556-12561. [CrossRef] 
27. Li, F.T.; Liu, Y.; Liu, R.H.; Sun, Z.M.; Zhao, D.S.; Kou, C.G. Preparation of Ca-doped $\mathrm{LaFeO}_{3}$ nanopowders in a reverse microemulsion and their visible light photocatalytic activity. Mater. Lett. 2010, 64, $223-225$. [CrossRef]

28. Li, S.; Jing, L.; Fu, W.; Yang, L.; Xin, B.; Fu, H. Photoinduced charge property of nanosized perovskite-type $\mathrm{LaFeO}_{3}$ and its relationships with photocatalytic activity under visible irradiation. Mater. Res. Bull. 2007, 42, 203-212. [CrossRef]

29. Parida, K.M.; Reddy, K.H.; Martha, S.; Das, D.P.; Biswal, N. Fabrication of nanocrystalline $\mathrm{LaFeO}_{3}: \mathrm{An}$ efficient sol-gel auto-combustion assisted visible light responsive photocatalyst for water decomposition. Int. J. Hydrog. Energy 2010, 35, 12161-12168. [CrossRef]

30. Thirumalairajan, S.; Girija, K.; Hebalkar, N.Y.; Mangalaraj, D.; Viswanathan, C.; Ponpandian, N. Shape evolution of perovskite $\mathrm{LaFeO}_{3}$ nanostructures: A systematic investigation of growth mechanism, properties and morphology dependent photocatalytic activities. RSC Adv. 2013, 3, 7549-7561. [CrossRef]

31. Jing, L.; Qu, Y.; Su, H.; Yao, C.; Fu, H. Synthesis of high-activity $\mathrm{TiO}_{2}$-based photocatalysts by compounding a small amount of porous nanosized $\mathrm{LaFeO}_{3}$ and the activity-enhanced mechanisms. J. Phys. Chem. C 2011, 115, 12375-12380. [CrossRef]

32. Dhinesh Kumar, R.; Thangappan, R.; Jayavel, R. Synthesis and characterization of $\mathrm{LaFeO}_{3} / \mathrm{TiO}_{2}$ nanocomposites for visible light photocatalytic activity. J. Phys. Chem. Solids 2017, 101, 25-33. [CrossRef]

33. Gao, K.; Li, S. Multi-modal $\mathrm{TiO}_{2}-\mathrm{LaFeO}_{3}$ composite films with high photocatalytic activity and hydrophilicity. Appl. Surf. Sci. 2012, 258, 6460-6464. [CrossRef]

34. Jamali, S.S.; Singh, D.; Tavakkoli, H.; Kaveh, F.; Tabari, T. Microwave-assisted synthesis of nanostructured perovskite-type oxide with efficient photocatalytic activity against organic reactants in gaseous and aqueous phases. Mater. Sci. Semicond. Process. 2017, 64, 47-54. [CrossRef]

35. Ye, Y.; Yang, H.; Li, R.; Wang, X. Enhanced photocatalytic performance and mechanism of Ag-decorated $\mathrm{LaFeO}_{3}$ nanoparticles. J. Sol-Gel Sci. Technol. 2017, 82, 509-518. [CrossRef]

36. Uyguner, C.S.; Bekbolet, M. Implementation of spectroscopic parameters for practical monitoring of natural organic matter. Desalination 2005, 176, 47-55. [CrossRef]

37. Sen-Kavurmaci, S.; Birben, N.C.; Tomruk, A.; Bekbolet, M. Characterization of organic matter in natural waters by EEM fluorescence properties. Desalin. Water Treat. 2016, 57, 2428-2436. [CrossRef]

38. Uyguner-Demirel, C.S.; Birben, C.; Bekbolet, M. Key role of common anions on the photocatalytic degradation profiles of the molecular size fractions of humic acids. Catal. Today 2013, 209, 122-126. [CrossRef]

39. Rusevova, K.; Köferstein, R.; Rosell, M.; Richnow, H.H.; Kopinke, F.-D.; Georgi, A. $\mathrm{LaFeO}_{3}$ and $\mathrm{BiFeO}_{3}$ perovskites as nanocatalysts for contaminant degradation in heterogeneous Fenton-like reactions. Chem. Eng. J. 2014, 239, 322-331. [CrossRef]

40. Uyguner, C.S.; Bekbolet, M. A review on the photocatalytic degradation of humic substances. In Control of Disinfection By-Products in Drinking Water Systems; Nikolau, A., Selcuk, H., Rizzo, L., Eds.; NOVA Science Publishers Inc.: New York, NY, USA, 2007; Chapter 7.4; pp. 419-446.

41. Bekbolet, M.; Sen-Kavurmaci, S. The effect of photocatalytic oxidation on molecular size distribution profiles of humic acid. Photochem. Photobiol. Sci. 2015, 14, 576-582. [CrossRef]

42. Kerc, A.; Bekbolet, M.; Saatci, A.M. Effects of oxidative treatment techniques on molecular size distribution of humic acids. Water Sci. Technol. 2004, 49, 7-12. [CrossRef]

43. Abbt-Braun, G.; Frimmel, F.H. Dissolved organic matter (DOM) in natural environments. In Biophysico-Chemical Processes Involving Natural Nonliving Organic Matter in Environmental Systems, 1st ed.; Senesi, N., Xing, B., Huang, P.M., Eds.; John Wiley \& Sons, Inc.: Hoboken, NJ, USA, 2009; pp. 367-406. ISBN 9780470413005.

(C) 2018 by the authors. Licensee MDPI, Basel, Switzerland. This article is an open access article distributed under the terms and conditions of the Creative Commons Attribution (CC BY) license (http:/ / creativecommons.org/licenses/by/4.0/). 